\title{
Biflavones and triterpenoids isolated from Ouratea castaneifolia (DC.) Engl., Ochnaceae
}

\author{
Luís Adriano S. do Nascimento, ${ }^{1}$ Giselle M. S. P. Guilhon, ${ }^{* 1}$ Mara S. P. Arruda, ${ }^{1}$ \\ Lourivaldo S. Santos, ${ }^{1}$ Alberto C. Arruda, ${ }^{1}$ Adolfo H. Müller, ${ }^{1}$ Milton N. da Silva, ${ }^{1}$ \\ Silvane T. Rodrigues, ${ }^{2}$ Mário G. de Carvalho ${ }^{3}$
}

\author{
${ }^{1}$ Faculdade de Química, Instituto de Ciências Exatas e Naturais, Universidade Federal do Pará, \\ Av. Augusto Corrêa, 1, 66075-110 Belém-PA, Brazil \\ ${ }^{2}$ Departamento de Botânica, Embrapa Amazônia Oriental, Tv. Enéas Pinheiro s/n, 66077-530 Belém-PA, Brazil \\ ${ }^{3}$ Departamento de Química, Instituto de Ciências Exatas, Universidade Federal Rural do Rio de Janeiro, BR-465, \\ km 7, 23851-970 Seropédica-RJ, Brazil
}

\begin{abstract}
RESUMO: "Biflavonas e triterpenóides isolados de Ouratea castaneifolia (DC.) Engl., Ochnaceae". O presente trabalho trata da investigação química das folhas e caule da espécie Ouratea castaneifolia (DC.) Engl., sobre a qual não há registros de estudos químicos ou farmacológicos anteriores. O estudo fitoquímico clássico dos extratos orgânicos do caule e das folhas de $O$. castaneifolia foi aliado à técnica da cromatografia líquida de alta eficiência (CLAE) e resultou na identificação de dezessete metabólitos: sete triperpenos (friedelina, $3 \beta$-friedelinol, $\alpha$-amirina, $\beta$-amirina, lupeol, taraxerol e germanicol), quatro esteróides (sitosterol, estigmasterol e os glucosídeos sitosteril 3-O- $\beta$-D-glicopiranosídeo e estigmasteril 3-O- $\beta$-D-glicopiranosídeo), uma isoflavona (5,7,4' -trimetoxiisoflavona), uma flavona (5,4' -diidroxi-7,3' ${ }^{\prime}, 5^{\prime}$-trimetoxiflavona), quatro biflavonas(amentoflavona, 7,7"-O-dimetil-amentoflavona, heveaflavonaetetrametilamentoflavona). A identificação das substâncias foi feita com base na análise de espectros de $\mathrm{RMN}$ de ${ }^{1} \mathrm{H},{ }^{13} \mathrm{C}$ e técnicas bidimensionais. As classes dos metabólitos identificados estão de acordo com aquelas citadas em estudos químicos do gênero Ouratea.
\end{abstract}

Unitermos: Ouratea castaneifolia, Ochnaceae, biflavonas, flavonóide, terpenóide.

\begin{abstract}
This paper presents the chemical investigation of the leaves and stems of Ouratea castaneifolia (DC.) Engl.. There are no chemical or pharmacological studies with this species. Classic phytochemical investigation of the organic extracts together with high pressure liquid chromatography (HPLC) procedures lead to the identification of seventeen metabolites: seven triterpenes (friedelin, 3 $\beta$-friedelinol, $\alpha$-amyrin, $\beta$-amyrin, lupeol, germanicol and taraxerol), four steroids (sitosterol, stigmasterol and the glycosides sitosteryl 3-O- $\beta$-D-glucopyranoside and stigmasteryl 3-O- $\beta$-D-glucopyranoside), one isoflavone (5,7,4'-trimethoxyisoflavone), one flavone (5,4'-dihydroxy-7,3',5'-trimethoxyflavone) and four biflavones (amenthoflavone, 7,7'O-dimethylamenthoflavone, heveaflavone and tetramethylamenthoflavone). The structures of the compounds were established by the analysis of ${ }^{1} \mathrm{H},{ }^{13} \mathrm{C}$ NMR spectra including bidimensional techniques. The classes of the identified metabolites are in agreement with previous studies of the Ouratea genus.
\end{abstract}

Keywords: Ouratea castaneifolia, Ochnaceae, biflavones, flavonoid, terpenoid.

\section{INTRODUCTION}

Ouratea and other genera of Ochnaceae are a rich source of flavonoids and biflavonoids and according to Suzart et al. (2007), the biflavonoids can be used as chemotaxonomic markers of the genus Ouratea as well as of Luxemburgia from the same botanic family. Lignans, triterpenes, diterpenes, steroids, monosaccharide, depsides, triglycerides and chloroisoflavones were also reported from this genus (Velandia et al., 1998a and 1998b; Carvalho et al., 2000; Manga et al., 2001; Mbing et al., 2003a and 2003b; Felício et al., 2004; Estevam et al., 2005). Some biflavonoids, as well as extracts of the Ouratea species showed important biological activities, as was previously published (Suzart et al., 2007).

Ouratea castaneifolia (DC.) Engl. Ochnaceae 
was collected in Marajo Island in the North of Brazil. This species is known in the Amazon region of Brazil as "farinha-seca", "mangue-do-mato" or "pau-de-serra" and its wood is used in small constructions and its bark is tonic and adstringent and contains tannins (Le Cointe, 1934). This work describes the phytochemical study of the extracts from the leaves and stems of $O$. castaneifoila.

\section{MATERIAL AND METHODS}

\section{General procedures}

Melting points are uncorrected. NMR spectra were recorded on a Mercury-300 Varian spectrometer (300 MHz for ${ }^{1} \mathrm{H}$ and $75 \mathrm{MHz}$ for ${ }^{13} \mathrm{C}$ ) using the solvent (DMSO- $\mathrm{d}_{6}, \mathrm{Me}_{2} \mathrm{CO}-\mathrm{d}_{6}, \mathrm{CD}_{3} \mathrm{OD}$ or $\mathrm{CDCl}_{3}$ ) and TMS as internal standard. Silica gel (Merck and Vetec 0.05-0.20 $\mathrm{mm}$ ) or Sephadex LH-20 was used on separations by column chromatography (CC). Silica gel HF (Merck) was used for TLC and revealed by UV (254 and $366 \mathrm{~nm}$ ), acid solution of ceric sulphate and exposure to iodine vapor. HPLC-UV analyses were performed using a Shimadzu (Shimadzu, Tokyo, Japan) liquid chromatography modular system consisting of two LC-10AD pumps, an UV-Vis Shimadzu SPD-10AV detector, and an LC Workstation Class LC-10 system for data processing. The samples were introduced using an injection valve fitted with $20 \mu \mathrm{L}$ loop (Rheodyne, California, USA). The mobile phase consisted of water:methanol:acetonitrile (24:40:36, isocratic mode) at a flow rate of $1 \mathrm{~mL} \cdot \mathrm{min}^{-1}$. A C18 column (Gemini, 250 $\mathrm{mm} \times 4.6 \mathrm{~mm} \times 5 \mu \mathrm{m}$ ) fitted with guard column (Gemini, $\mathrm{C} 18,4 \mathrm{~mm} \times 3 \mathrm{~mm} \times 5 \mu \mathrm{m}$ ) was utilized. UV detection was performed at $330 \mathrm{~nm}$.

\section{Plant material}

Leaves and stems of Ouratea castaneifolia (DC.) Engl. Ochnaceae were collected in Salvaterra (Marajó Island, State of Pará, Brazil) and identified by one of the authors (S.T.R.). A voucher specimen (IAN 172171) is deposited at the herbarium of Embrapa-Amazônia Oriental (Belém, Brazil).

\section{Extraction and isolation}

Dried and powdered leaves $(2500 \mathrm{~g})$ and stems (1880 g) were extracted with $n$-hexane, dichloromethane and methanol by percolation at room temperature. The solutions of leaves (L) and stems (S) were concentrated under vacuum to yield the $n$-hexane $(\mathrm{H})$, dichloromethane (D) and methanolic (M) extracts from the leaves (extract LH: $28.25 \mathrm{~g}$, extract LD: $51.85 \mathrm{~g}$ and extract LM: 238.10 g) and stems (extract SH: $3.40 \mathrm{~g}$, extract SD: $2.30 \mathrm{~g}$, extract SM: $32.00 \mathrm{~g})$. Extracts LH (28.25 g), LD (25.00 g) and SD $(2.30 \mathrm{~g})$ were fractionated by CC on silica gel using mixtures of hexane with EtOAc and $\mathrm{MeOH}$ gradually increasing polarity as elluents. The fractions were purified using similar $\mathrm{CC}$ procedures.

The fractions from LH extract eluted with $n$-hexane:EtOAc (6:8) afforded two mixtures of substances, one of compounds 7-11 (102 mg) and the other of 12-13 $(11 \mathrm{mg})$. The fraction from LD extract eluted with EtOAc $(100 \%)$, named as BF, was analyzed by ${ }^{1} \mathrm{H}$ NMR spectrum and characteristics signals of a mixture of biflavonoids were identified. After successive $\mathrm{CC}$ procedures, including the use of Sephadex LH-20 and methanol as elluent, no separation was achieved; fraction BF was than submitted to HPLC (chromatogram on Figure 1) yielding compounds $\mathbf{1 4}(4 \mathrm{mg}), \mathbf{1 5}(4 \mathrm{mg}), \mathbf{1 6}(4 \mathrm{mg})$ and $\mathbf{1 7}(7 \mathrm{mg})$. Compound 4 was further identified by HPLC from fraction BF. Part of the extract LM (20 g) was suspended on $\mathrm{MeOH}: \mathrm{H}_{2} \mathrm{O}$ (3:1) and successively extracted with $\mathrm{CHCl}_{3}$, EtOAc and $n$ - $\mathrm{BuOH}$ yielding the $\mathrm{CHCl}_{3}$, EtOAc and $n$-BuOH phases. During concentration of the $\mathrm{CHCl}_{3}$ phase from LM extract, a pale yellow solid precipitated and was washed with methanol affording compound $17(53 \mathrm{mg})$. The HPLC chromatogram of the $\mathrm{CHC}_{13}$ phase from methanolic extract partition was similar to $\mathrm{BF}$ fraction.

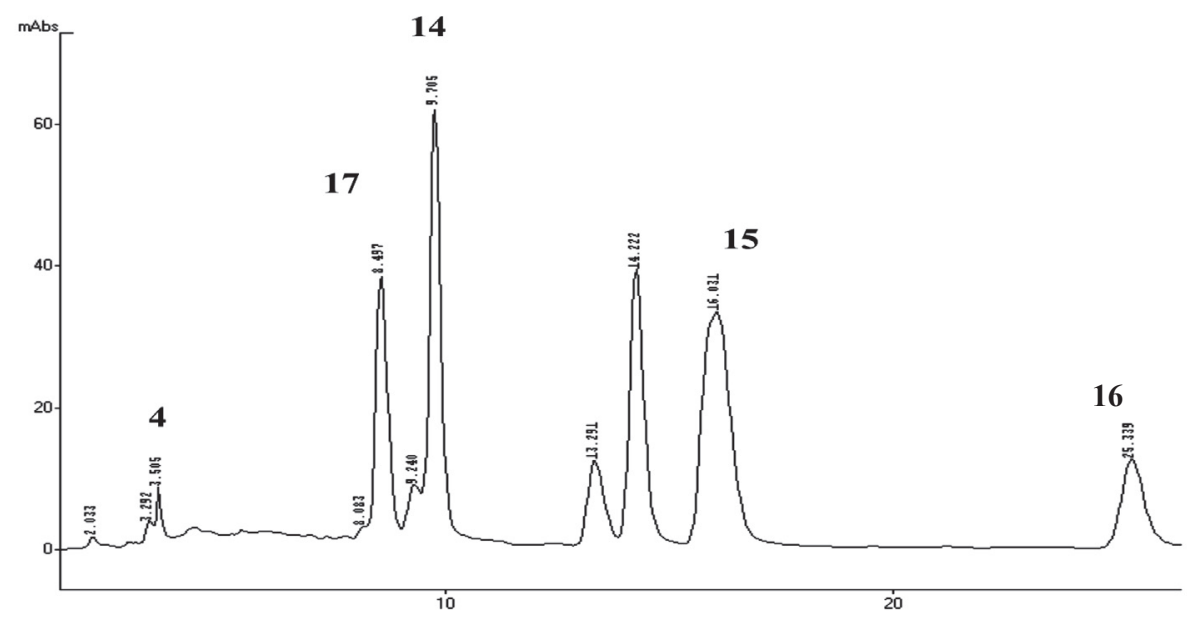

Figure 1. Chromatogram of fraction BF from Ouratea castaneifolia (DC.) Engl., Ochnaceae, eluted with $\mathrm{H}_{2} \mathrm{O}: \mathrm{MeOH}: \mathrm{MeCN}$ (24:40:36). Flow $1 \mathrm{~mL} / \mathrm{min}$. UV Detection: $\lambda=330 \mathrm{~nm}$. 
During the concentration of the $n$-hexane solution of the stems (solution SH), a solid material precipitated and was purified by recristalization with $n$-hexane and EtOAc affording a mixture of substances $\mathbf{1}$ and $\mathbf{2}(16 \mathrm{mg})$. Repeated CC procedures of the fractions of extract SD elluted with $n$-hexane:EtOAc (2:8) afforded compound 3 $(25 \mathrm{mg})$; the fraction elluted with $n$-hexane:EtOAc(1:1) yielded compound $4(5 \mathrm{mg})$. The fractions from the $\mathrm{SM}$ extract $(32.00 \mathrm{~g})$ were purified by $\mathrm{CC}$ eluting with hexane:EtOAc (25:75) and EtOAc:MeOH (9:1) affording additional quantities of compound $\mathbf{1 0}(8 \mathrm{mg})$ and a mixture of compounds 5 and $\mathbf{6}(20 \mathrm{mg})$.

\section{RESULTS AND DISCUSSION}

The chemical study of the stems of Ouratea castaneifolia (DC.) Engl. Ochnaceae lead to the identification of the triterpenes friedelin (1) (Mahato \& Kundu, 1994) and 3ß-friedelinol (2) (Salazar et al., 2000), the isoflavone 4',5,7-trimethoxyisoflavone (3) (Jha et al., 1980; Wang, 2005) and the flavone 4',5-dihydroxy3',5',7-trimethoxyflavone (4) (Zahir et al., 1996) and two glycosides 5 and $\mathbf{6}$ identified sitosteryl and stigmasteryl 3-O- $\beta$-D-glucopyranosides (Chaurasia \& Wichth, 1987), respectively.

Table 1. ${ }^{1} \mathrm{H}(300 \mathrm{MHz})$ and ${ }^{13} \mathrm{C}(75 \mathrm{MHz}) \mathrm{NMR}$ spectral data of 1 in DMSO-d 6 . Chemical shifts are in $\delta$ (ppm) and coupling constants (J) in $\mathrm{Hz}$.

\begin{tabular}{|c|c|c|c|c|c|}
\hline \multirow{2}{*}{$\mathrm{C}$} & \multicolumn{2}{|c|}{ HMQC $\left({ }^{1} J_{\mathrm{CH}}\right)$} & \multirow{2}{*}{\multicolumn{3}{|c|}{$H M B C\left({ }^{2,3} \mathrm{~J}_{\mathrm{H}-\mathrm{C}}\right)$}} \\
\hline & $\delta_{\mathrm{CH}}$ & $\delta_{\mathrm{H}}(\mathrm{mult}, \mathrm{Hz})$ & & & \\
\hline 3 & 103.3 & $6.76(\mathrm{~s})$ & \multicolumn{3}{|c|}{ C-2,C-4,C-10,C-1' } \\
\hline $3 "$ & 102.7 & $6.68(\mathrm{~s})$ & \multicolumn{3}{|c|}{$\mathrm{C}-2 ", \mathrm{C}-4 ", \mathrm{C}-10 ", \mathrm{C}-1 "$} \\
\hline 6 & 98.2 & $6.31(\mathrm{~d}, 2.4)$ & \multicolumn{3}{|c|}{ C-7,C-8,C-10 } \\
\hline 8 & 92.9 & $6.66(4,2.4)$ & \multicolumn{3}{|c|}{ C-6,C-9,C-10 } \\
\hline $6 "$ & 95.6 & $6.60(\mathrm{~s})$ & \multicolumn{3}{|c|}{ C-7”,C-8”,C-10" } \\
\hline $2^{\prime}$ & 131.5 & $8.09(\mathrm{~s}, 2.4)$ & \multicolumn{3}{|c|}{ C-2,C-4',C-6',C-8'” } \\
\hline 5 & 128.3 & $7.26(\mathrm{~d}, 8.7)$ & \multicolumn{3}{|c|}{$\mathrm{C}-1^{\prime}, \mathrm{C}-3^{\prime}$} \\
\hline $6^{\prime}$ & 128.2 & $8.05(\mathrm{dd}, 8.7,2.4)$ & \multicolumn{3}{|c|}{$\mathrm{C}-2^{\prime}$} \\
\hline $2 ", 6 "$, & 128.4 & $7.65(\mathrm{~d}, 8.7)$ & \multicolumn{3}{|c|}{ C-3"”,5"',C-2",C-4"” } \\
\hline $3 " ', 5 "$ & 116.0 & $6.84(\mathrm{~d}, 8.7)$ & \multicolumn{3}{|c|}{$\mathrm{C}-2$ '”, 6 "', C-1"' } \\
\hline $\mathrm{MeO}-7$ & 56.6 & $3.82(\mathrm{~s})$ & \multicolumn{3}{|c|}{$\mathrm{C}-7$} \\
\hline MeO-7" & 56.2 & 3.83)s) & \multicolumn{3}{|c|}{ C-7" } \\
\hline $\mathrm{HO}-5$ & - & $12.95(\mathrm{~s})$ & \multicolumn{3}{|c|}{ C-6,C-10 } \\
\hline HO-5” & - & $13.24(\mathrm{~s})$ & \multicolumn{3}{|c|}{ C-6",C-10" } \\
\hline \multicolumn{6}{|c|}{ Chemical shift of quaternary carbons } \\
\hline $\mathrm{C}$ & $\delta \mathrm{C}$ & $\mathrm{C}$ & $\delta \mathrm{C}$ & $\mathrm{C}$ & \\
\hline 2 & 164.2 & $8 "$ & 105.0 & $10 ”$ & 104.2 \\
\hline $2 "$ & 16164.2 & 7 & 165.3 & 1 ' & 121.1 \\
\hline 4 & 182.1 & $7 "$ & 162.8 & $3^{\prime}$ & 119.8 \\
\hline $4 "$ & 182.5 & 9 & 157.7 & 4 ' & 159.6 \\
\hline 5 & 161.4 & $9 "$ & 153.7 & $1 \%$, & 121.3 \\
\hline $5 "$ & 161.5 & 10 & 104.8 & $4 "$, & 161.3 \\
\hline
\end{tabular}

${ }^{\mathrm{a}}$ Homonuclear $2 \mathrm{D}-{ }^{1} \mathrm{H}-{ }^{1} \mathrm{H}-\mathrm{COSY}$ spectra were also used in these assignments.

The triterpenes, $\alpha$-amyrin (7), $\beta$-amyrin (8), lupeol (9), taraxerol (10) and germanicol (11) (Mahato \& Kundu, 1994) and the steroids mixture, sitosterol (12) (Nes et al., 1992) and stigmasterol (13) (Forgo \& Kövér, 2004), were identified in the extract from the leaves of $O$. castaneifolia. The biflavones 14-17 were also isolated from the leaves of the plant and were identified as 7,7"-di$O$-methylamenthoflavone (Gu et al., 1990), heveaflavone
(4"',7,7"-tri-O-methylamenthoflavone) (Carbonezi et al., 2007), 4',4"',7,7'-tetra- $O$-methylamenthoflavone (Markham et al., 1987) and amenthoflavone (Dora \& Edwards, 1991; Markham et al., 1987), respectively. 
<smiles></smiles>

\begin{tabular}{c|cccc} 
& $\mathrm{R}_{1}$ & $\mathrm{R}_{2}$ & $\mathrm{R}_{3}$ & $\mathrm{R}_{4}$ \\
\hline $\mathbf{1 4}$ & $\mathrm{Me}$ & $\mathrm{H}$ & $\mathrm{Me}$ & $\mathrm{H}$ \\
$\mathbf{1 5}$ & $\mathrm{Me}$ & $\mathrm{H}$ & $\mathrm{H}$ & $\mathrm{H}$ \\
$\mathbf{1 6}$ & $\mathrm{Me}$ & $\mathrm{Me}$ & $\mathrm{Me}$ & $\mathrm{Me}$ \\
$\mathbf{1 7}$ & $\mathrm{H}$ & $\mathrm{H}$ & $\mathrm{H}$ & $\mathrm{H}$
\end{tabular}

Compound 3 was isolated from $O$. hexasperma (Moreira et al., 1994) and heveaflavone (15) from $O$. multiflora (Carbonezi et al., 2007); amenthoflavone (15) is common in Ouratea (Felicio et al., 2004; Felicio et al., 2001; Velandia et al., 2002). To our knowlegment, this is the first occurrence of germanicol (11), 4',5-dihydroxy3',5',7-trimethoxyflavone (4) and of the biflavone 7,7'-di$O$-methylamentoflavone (14) in the Ouratea genus.
All the NMR data of compound $\mathbf{1 5}$ (heveaflavone) were in agreement with the literature data (Carbonezi et al., 2007), except for the attribution of the HO-5 and HO-5" that were changed. In the HMBC of 15, the signal at $\delta_{\mathrm{H}} 12.95(\mathrm{OH}-5)$ showed ${ }^{2,3} \mathrm{JCH}$ correlation with $\delta_{\mathrm{c}} 98.2$ (C-6) and the signal at $\delta_{\mathrm{H}} 13.21\left(\mathrm{OH}-5\right.$ ") showed ${ }^{2,3} \mathrm{JCH}$ correlation with $\delta \mathrm{c} 95.6$ (C-6").

The ${ }^{13} \mathrm{C}$ NMR data of compound $\mathbf{1 4}$ are being published for the first time. It were made by the $1 \mathrm{D}$ (BBD and DEPT) and 2D (HMQC and HMBC) NMR experiments analysis (Table 1). The ${ }^{1} \mathrm{H}$ NMR spectra [1D and $\left.2 \mathrm{D}\left({ }^{1} \mathrm{H}-{ }^{1} \mathrm{H}-\mathrm{COSY}\right)\right]$ of compound $\mathbf{1 4}$ showed signals of two chelated hydroxyls ( $\delta_{\mathrm{H}} 12.95$ and 13.24), hydrogens of two aromatic methoxyl groups, two hydrogens of ring A (meta coupled), one non coupled hydrogen (ring A"), the hydrogens of a 1,3,4-trisubstituted aromatic ring (ring $\mathrm{B})$ and the hydrogens of a para-substituted aromatic ring (Ring B"'). These 'H NMR data are in accordance to those published by $\mathrm{Gu}$ et al. (1990). The ${ }^{13} \mathrm{C}$ NMR spectrum of compound 14 showed thirty signals, ten signals were attributed to twelve $\mathrm{sp}^{2} \mathrm{CH}$ (including the two signals atributted to C-2" and C-6" " and to C-3" " and C-5" "), two $\mathrm{sp}^{3}$ carbons $\left(\delta_{\mathrm{cH}} 56.2\right.$ and 56.6), sixteen $\mathrm{sp}^{2}$ quaternary carbons and two carbonyl groups ( $\delta \mathrm{c} 182.1$ and 182.5). The structure of $\mathbf{1 4}$ was confirmed on the basis of HMBC spectrum (Table 1, Figure 1), which showed heteronuclear long range couplings ${ }^{2,3} \mathrm{JCH}$ of $\mathrm{H}-2$ ' with $\mathrm{C}-8$ " and of H-6" with C-8". These data together with the absence of

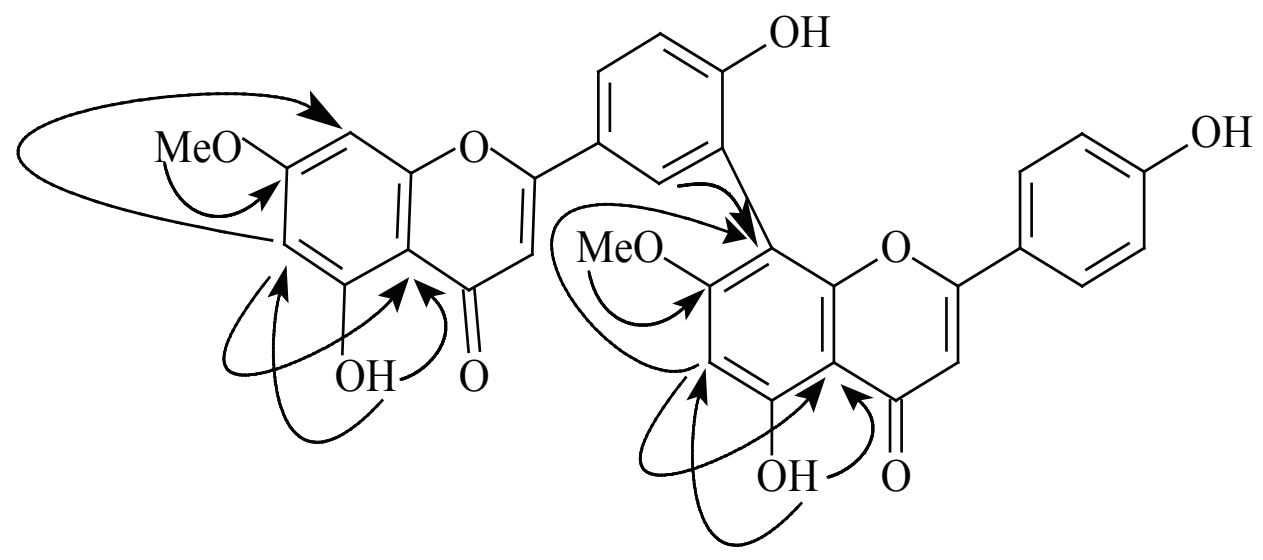

Figure 2. Some ${ }^{2,3} \mathrm{~J}_{\mathrm{CH}}$ long-range correlations on the HMBC of compound $\mathbf{1 4}$.

correlations with C-9", are characteristic of biflavonoids with an amenthoflavone skeleton (Goh et al., 1992). The localization of the methyl groups on compound $\mathbf{1 4}$ was deduced by comparison of the chemical shifts on the ${ }^{13} \mathrm{C}$ NMR spectra with those of amenthoflavone taking in account the protection effect caused by the presence of these groups on the vicinal carbons as described in the literature (Markham et al., 1987). The HMBC experiments also showed correlations of the quaternary carbons C-7" ( $\delta \mathrm{c} 162.8)$ and $\mathrm{C}-7$ ( $\left.\delta_{\mathrm{c}} 165.2\right)$ with the hydrogens of the methoxyl groups at $\delta$ н 3.83 (OMe-7") and 3.82 (OMe-7), respectively.

\section{ACKNOWLEDGEMENTS}

We would like to thank CAPES for the grant (LASN) and CNPq and FUNTEC-SECTAM for the financial support. 


\section{REFERENCES}

Carbonezi CA, Hamerski L, Gunatilaka AAL, Cavalheiro A, Castro-Gamboa1 I, Silva DHS, Furlan M, Young MCM, Lopes MN, Bolzani VS 2007. Bioactive flavone dimers from Ouratea multiflora. Rev Bras Farmacogn 17: 319324.

Carvalho MG de, Carvalho GJA de, Braz-Filho R 2000. Chemical constituents from Ouratea floribunda: complete ${ }^{1} \mathrm{H}$ and ${ }^{13} \mathrm{C}$ NMR assignments of atranorin and its new acetyl derivative. J Braz Chem Soc 11: 143-147.

Chaurasia N, Wichth MJ 1987. Sterols and steryl glycosides from Urtica dioica. J Nat Prod 50: 881-885.

Dora G, Edwards JM 1991. Taxonomic status of Lanaria lanata and isolation of a novel biflavone. J Nat Prod 54: 796801.

Estevam CS, Oliveira FM, Conserva LM, Lima LF, Barros ECP, Barros SCP, Rocha EMM, Andrade EHA 2005. Constituintes químicos e avaliação preliminar in vivo da atividade antimalárica de Ouratea nitida Aubl (Ochnaceae). Rev Bras Farmacogn 15: 195-198.

Felicio JD, Rossi MH, Braggio MM, Gonçalez E, Pak A, Cordeiro I, Felicio RC 2004. Chemical constituents from Ouratea parviflora. Biochem Syst Ecol 32: 79-81.

Felicio JD, Rossi MH, Park HR, Gonçalez E, Braggio MN, David JN, Cordeiro I 2001. Biflavonoids from Ouratea multiflora. Fitoterapia 72: 453-455.

Forgo P, Kövér KE 2004. Gradient enhanced seletive experiments in the ${ }^{1} \mathrm{H}$ NMR chemical shift assignment of the skeleton and side-chain resonances of stigmasterol, a phytosterol derivative. Steroids 69: 43-50.

Goh SH, Jantan I, Waterman PG 1992. Neoflavonoid and biflavonoid constituents of Calophyllum inophylloide. $J$ Nat Prod 55: 1415-1420.

$\mathrm{Gu}$ YL, Xu YM, Fang SD, He QM 1990. The chemical constituents from Podocarpus imbricatus. Acta Bot Sin 32: 631-636.

Jha HC, Zilliken F, Breitmaier E 1980. Carbon-13 NMR shifts and carbon-hydrogen coupling constants of deoxybenzoins and related acetophenones. Can J Chem 58: 1211-19.

Le Cointe P 1934. Árvores e plantas úteis (indígenas e aclimatadas). Série: AAmazônia Brasileira, $n^{\circ} 3$. Livraria Clássica, Belém.

Mahato SB, Kundu AP 1994. ${ }^{13} \mathrm{C}$ NMR spectra of pentacyclic triterpenoids-A compilation and some salient features. Phytochemistry 37: 1517-1575.

Manga SSE, Messanga BB, Sondengam BL 2001. 7,8Dihydrobenzofuranones from Ouratea reticulata. Fitoterapia 72: 706-708.

Markham KR, Sheppard C, Geiger H 1987. 13C NMR Studies of some naturally occurring amentoflavone and hinokiflavone biflavonoids. Phytochemistry 26: 3335 3337.

Mbing JN, Bassomo MY, Pegnyemb DE, Tih RG, Sondengam BL, Blond A, Bodo B 2003a. Constituents of Ouratea flava. Biochem Syst Ecol 31: 215-217.

Mbing JN, Pegnyemb DE, Tih RG, Sondengam BL, Blond A, Bodo B 2003b. Two biflavonoids from Ouratea flava stem bark. Phytochemistry 63: 427-431.

Moreira IC, Sobrinho DC, Carvalho MG de, Braz-Filho R 1994. Isoflavanone dimers hexaspermone $\mathrm{A}, \mathrm{B}$ and $\mathrm{C}$ from Ouratea hexasperma. Phytochemistry 35: 1567-1572.
Nes WD, Norton RA, Benson M 1992. Carbon ${ }^{13} \mathrm{C}$ NMR studies on sitosterol biosynthesized from $\left[{ }^{13} \mathrm{C}\right]$ mevalonates. Phytochemistry 31: 805-811.

Salazar GCM, Silva GDF, Duarte LP, Vieira Filho SA, Lula IS 2000. Two epimeric friedelane triterpenes isolated from Maytenus truncata Reiss: ${ }^{1} \mathrm{H}$ and ${ }^{13} \mathrm{C}$ chemical shift assignments. Magn Reson Chem 38: 977-980.

Suzart LR, Daniel JFS, Carvalho MG, Kaplan MAC 2007. Biodiversidade flavonoídica e aspectos farmacológicos em espécies dos gêneros Ouratea e Luxemburgia (Ochnaceae). Quim Nova 30: 984-987.

Velandia JR, Carvalho MG de, Braz Filho R 1998a. Ácido ent-16a,17-diidroxicauran-19-óico isolado de Ouratea semiserrata e os desafios estereoquímicos dos carbonos quirais C-4 e C-16. Quim Nova 21: 397-404.

Velandia JR, Carvalho MG de, Braz Filho R 1998b. Novel trichloro- and tetrachloroisoflavone isolated from Ouratea semiserrata. Nat Prod Lett 12: 191-198.

Velandia JR, Carvalho MG de, Braz Filho R, Werle AA 2002. Biflavonoids and a glucopyranoside derivative from Ouratea semiserrata. Phytochem Analysis 13: 283-292.

Wang GSF, Jiang Q, Ye YH, Li Y, Tan RX 2005. Genistein derivatives as selective strogen receptor modulators: Sonochemical synthesis and in vivo anti-osteoporotic action. Bioorgan Med Chem 13: 4880-4890.

Zahir A, Jossang A, Bodo B 1996. DNA Topoisomerase I inhibitors: Cytotoxic flavones from Lethedon tannaensis. J Nat Prod 59: 701-703. 